\title{
Kualitas dan Nilai Nutrisi Silase Daun Sorgum Manis untuk Pakan Ternak
}

\author{
Quality and Nutrition Value of Silage from Sweet Sorghum Leaves for \\ Forage
}

\author{
Simping Yuliatun ${ }^{1)}$ dan Triantarti ${ }^{1)}$ \\ 1) Pusat Penelitian Perkebunan Gula Indonesia, Pasuruan - Jawa Timur \\ Alamat korespondensi, Email: simping7@gmail.com
}

\begin{abstract}
ABSTRAK
Biomassa sorgum manis yang berupa daun sorgum berpotensi sebagai pakan ternak yang melimpah saat panen. Pembuatan silase daun sorgum merupakan upaya mendapatkan pakan yang tersedia sepanjang musim dengan cara diawetkan melalui proses ensilasi. Tujuan penelitian ini adalah mengetahui kualitas dan nilai nutrisi silase daun sorgum manis. Pembuatan silase daun sorgum dilakukan dengan menggunakan bakteri Lactobacillus plantarum dengan perlakuan penambahan tetes dan urea. Contoh sebelum dan sesudah ensilasi dianalisis $\mathrm{pH}$, acid detergent fiber (ADF), neutral detergent fiber (NDF), selulosa, lignin, kadar air, kadar $\mathrm{N}$ dan kadar abu. Hasil penelitian menunjukkan ensilasi dapat menurunkan $\mathrm{pH}$ silase daun sorgum dengan penurunan $\mathrm{pH}$ antara 0,13-1,33 poin. Kualitas silase daun sorgum tergolong sedang hingga sangat baik dengan nilai FN 56-92. Nutrisi silase daun sorgum berdasarkan kandungan protein yang tersedia termasuk kelompok kualitas cukup dan sedang yaitu berkisar antara 8-12\%. Nilai nutrisi silase daun sorgum berdasarkan kandungan serat yang sulit dicerna (ADF), total serat yang dapat dicerna (TDN) dan energi metabolisme pakan (ME) termasuk dalam kelompok kualitas baik hingga sangat baik dengan nilai ADF kurang dari 37\%, TDN lebih dari 54\%, dan ME lebih dari 0,94 Mkal/lb..
\end{abstract}

Kata kunci: daun sorgum manis, pakan, kualitas silase dan nilai nutrisi

\section{ABSTRACT}

Sweet sorghum biomass such as leaves are abundant materials on the harvesting season that are potential for forage of cattle. Sorghum silage is made as an effort to obtain continued availability of forage for a long season using ensilage method. The purpose of this research was to determine the quality and nutritional value of silage of sweet sorghum leaves. Silage of sorghum leaves was made by using Lactobacillus plantarum with the addition of molasses and urea. Sweet sorghum leaves before and after ensilage were analyzed for $\mathrm{pH}$, acid detergent fiber $(A D F)$, neutral detergent fiber (NDF), cellulose, lignin, moisture content, $N$ content and ash content. The results showed that ensilage could reduce the $\mathrm{pH}$ of the silage from sorghum leaves with a decrease in $\mathrm{pH}$ between 0.13 to 1.33 points. The quality of silage of sorghum leaves were moderate to very good with the FN value 56-92. The nutrition content of silage based on its protein availability was categorized as sufficient and moderate quality groups ranging from 8-12\%. The nutrition value of sorghum silage based on indigestible fiber $(A D F)$, total digestible fiber (TDN) and energy metabolism of feed 
(ME) was included in the group of good to very good quality with a value of less than $37 \%$ $A D F$, over $54 \%$ of TDN, and more than 0.94 Mkal/lb of ME.

Key words: leaves of sweet sorghum, forage, silage quality and nutrition value

\section{PENDAHULUAN}

Silase adalah pakan yang diawetkan melalui proses ensilasi, yaitu proses pengawetan pakan atau hijauan dengan menggunakan kerja spontan fermentasi asam laktat dalam kondisi anaerob. Bakteri asam laktat epifit (BAL) memfermentasi karbohidrat terlarut air dalam tanaman menjadi asam laktat dan sebagian kecil diubah menjadi asam asetat (Pahlow et al., 2003).

Prinsip pembuatan silase adalah fermentasi hijauan oleh bakteri asam laktat secara anaerob. Penambahan bakteri asam laktat dalam proses pembuatan silase bertujuan untuk menfermentasi gula (water soluble carbohydrate) dari tanaman menjadi asam laktat dan sedikit asam asetat. Adanya asam-asam ini akan menurunkan $\mathrm{pH}$ silase, sehingga dapat menghambat pertumbuhan bakteri pembusuk lainnya (Moran, 2005). Bila proses fermentasi (ensilasi) dilakukan dengan kondisi tidak tepat maka akan dihasilkan bermacam-macam asam seperti asam butirat, sehingga menurunkan palatabilitas dan mutu silase (Gallo et al., 2016).

Hijauan yang dibuat silase lebih awet dan dapat disimpan beberapa tahun. Teknik silase sangat menguntungkan. Teknik ini memungkinkan mengawetkan kelebihan hijauan pada musim penghujan. Dengan teknik silase kita dapat memanen hijauan pada saat produktivitas tertinggi sehingga produksi per hektar meningkat. Selain itu, mendatangkan hijauan dalam jumlah besar (efisiensi transportasi) serta mengawetkan limbah pertanian yang tersedia dalam jumlah besar dalam semusim dapat dilakukan dengan teknik silase untuk dipergunakan pada saat hijauan sulit diperoleh (Sariubang dan Nurhayu, 2015).

Silase sorgum adalah silase yang hijauannya berasal dari tanaman sorgum. Kualitas silase ditentukan oleh nilai nutrisi silase dalam bahan tersebut (Govea et al, 2010 dan Oliveira et al., 2017), perkembangan suhu selama fermentasi dan tipe fermentasinya. Nilai nutrisi akan berbeda pada bagian jaringan tanaman yang berbeda pula. Nilai nutrisi bahan berbanding lurus dengan digestibilitas bahan itu. Jaringan tanaman sorgum terdiri dari epidermis, mesofil dan parenkim. Digestibilitas jaringan tanaman akan menurun pada urutan jaringan mesofil > epidermis > parenkim (Govea et al, 2010). Tingkat kedewasaan tanaman juga mempengaruhi nilai digestibilitasnya. Batang tanaman sorgum menempati bagian paling besar pada semua tingkatan kedewasaan tanaman. Menurut Govea et al. (2010) digestibilitas batang sorgum lebih tinggi dibandingkan daun sorgum, tetapi sama dengan bagian pucuk tanaman sorgum.

Kualitas silase sangat dipengaruhi oleh pH. Silase yang baik kualitasnya memiliki pH 4,2 dengan kandungan asam laktat antara 1,5 $-2,5 \%$; asam asetat $0,5-0,8 \%$; asam propionat dan asam butirat $<0,1 \%$. Kualitas silase sebagai pakan dipengaruhi oleh nilai-nilai nutrisi yang terkandung dalam silase tersebut seperti kadar protein, total nutrisi yang dapat dicerna dan energi yang dapat digunakan untuk metabolismenya (Quarberg, 2011).

Prinsip dasar pembuatan silase memacu terjadinya kondisi anaerob dan asam dalam waktu singkat (Manyawu et al, 2016). Ada 4 
hal paling penting agar diperoleh kondisi tersebut yaitu menghilangkan udara dengan cepat, menghasilkan asam laktat yang membantu menurunkan $\mathrm{pH}$, mencegah masuknya oksigen ke dalam silo dan menghambat pertumbuhan jamur selama penyimpanan.

Fermentasi silase dimulai saat oksigen telah habis digunakan oleh sel tanaman. Bakteri menggunakan karbohidrat mudah larut untuk menghasilkan asam laktat dalam menurunkan $\mathrm{pH}$ silase. Tanaman di lapangan mempunyai $\mathrm{pH}$ yang bervariasi antara 5 dan 6, setelah difermentasi turun menjadi 3,6-4,5 (Manyawu et al., 2016). Penurunan $\mathrm{pH}$ yang cepat membatasi pemecahan protein dan menghambat pertumbuhan mikroorganisme anaerob merugikan seperti Enterobacteria dan Clostridia. Produksi asam laktat yang berlanjut akan menurunkan $\mathrm{pH}$ yang dapat menghambat pertumbuhan semua bakteri.

Proses pembuatan silase dipengaruhi oleh tingkat kematangan dan kelembaban bahan (Khan et al., 2015). Tingkat kematangan tanaman yang tepat memastikan tercukupinya jumlah gula fermentasi (fermentable sugar) untuk proses pertumbuhan bakteri silase dan memberikan nutrisi maksimum untuk ternak. Tingkat kematangan juga memiliki pengaruh yang besar pada kelembaban hijauan pakan ternak, tercukupinya kelembaban untuk fermentasi bakteri sangat penting dan membantu dalam proses pembungkusan untuk mengeluarkan oksigen dari silase. Selain itu tingkat kematangan bahan juga mempengaruhi kemampuan daya cerna (digestibility) usus terhadap nutrisi dalam silase.

Ukuran bahan juga mempengaruhi proses pembuatan silase. Ukuran bahan yang baik antara 1-3 cm diperoleh dengan pemotongan. Potongan material tanaman dengan panjang 1-3 cm akan menghasilkan silase dengan kepadatan yang ideal dan memudahkan pada saat proses pemanenan.
Memotong hijauan pakan ternak terlalu panjang juga dapat mengakibatkan silase sulit untuk merapat, serta udara akan terperangkap di dalam silase dapat mengakibatkan pemanasan bunker silo. Setelah diisi, silo harus ditutup rapat dengan penutup kedap udara untuk menghindari penetrasi udara dan air hujan ke dalam silase.

Dalam upaya memanfaatkan daun sorgum menjadi silase perlu dilakukan penelitian yang bertujuan untuk mendapatkan silase daun sorgum manis yang memiliki mutu dan nilai nutrisi yang baik.

\section{METODE}

\section{Waktu dan Tempat}

Penelitian ini dilakukan pada bulan Juli sampai dengan September 2013 di laboratorium Bioteknologi Pusat Penelitian Perkebunan Gula Indonesia (P3GI), Pasuruan.

\section{Bahan dan Alat}

Bahan yang digunakan daun sorgum varietas B6 dari Jepang yang ditanam di lokasi Kebun Percobaan P3GI Pasuruan, tetes, urea, dan mikroba Lactobacillus plantarum dalam media cair. Alat yang digunakan meliputi vacuum sealer, timbangan/neraca, spatula, beaker glass, pipet volum, alat pemotong, dan kantong plastik

\section{Metode pembuatan silase}

Metode pembuatan silase memiliki beberapa tahap aktivitas. Daun sorgum varietas B6 dipisahkan, selanjutnya dilayukan di bawah sinar matahari sekitar 2 jam. Daun sorgum tersebut kemudian dipotong-potong dengan ukuran 3-5 cm. Sebanyak 250 gram daun sorgum yang telah dipotong digunakan untuk bahan silase. Percobaan dilakukan dalam 2 kali ulangan dengan komposisi bahan silase ditampilkan pada Tabel 1 . 
Masing-masing contoh perlakuan selanjutnya dicampur sampai homogen dan dimasukkan ke dalam kantong plastik. Kemudian contoh perlakuan tersebut divakumkan hingga tidak ada udara di dalamnya dengan menggunakan alat vacuum sealer. Contoh dalam kantong plastik lalu diinkubasi pada kondisi anaerob selama 3 minggu pada suhu kamar. Analisa contoh dilakukan sebelum dan sesudah ensilasi meliputi acid detergent fiber (ADF), neutral detergent fiber (NDF), selulosa dan lignin dengan Metode Van Soest and Wine (1975), $\mathrm{pH}$, kadar air dengan pengeringan contoh dalam oven pada suhu $105{ }^{\circ} \mathrm{C}$ selama 4-5 jam hingga diperoleh berat konstan, kadar $\mathrm{N}$ dengan metode Kjeldhal dan kadar abu dilakukan dengan mengabukan pada tanur suhu $600{ }^{\circ} \mathrm{C}$ selama 2 jam

\section{Perhitungan untuk Penentuan Nilai-Nilai antara lain :}

1. Penentuan nilai protein kasar (CP) dengan persamaan :

$$
\mathrm{CP}(\% \mathrm{BK})=\text { kadar } \mathrm{N} \times 6,25
$$

2. Penentuan Nilai Fleigh (FN) silase dengan persamaan :

$$
\mathrm{FN}=220+(2 \times \text { Berat Kering \% - 15) }-
$$$$
(40 \times \mathrm{pH})
$$

3. Penentuan total digestible nutrient (TDN) silase sorgum dengan persamaan :

$$
\operatorname{TDN}(\%)=87,1-(\operatorname{ADF} \times 0,848)
$$

4. Penentuan Metabolizable Energy (ME) dengan persamaan :

$\mathrm{ME}(\mathrm{kcal} / \mathrm{lb})=(\mathrm{TDN} \times 0,2004) \times(96-$ $(0,202 \times \mathrm{CP}))$

Tabel 1. Komposisi bahan dalam pembuatan silase daun sorgum

Table 1. Composition of raw materials for ensilage of sorghum leaves

\begin{tabular}{cl}
\hline $\begin{array}{c}\text { No perlakuan } \\
\text { Treatments no. }\end{array}$ & \multicolumn{1}{c}{$\begin{array}{c}\text { Perlakuan } \\
\text { Treatments }\end{array}$} \\
\hline 1 & $\begin{array}{l}\text { Daun sorgum }+5 \% \text { tetes } \\
\text { Sorgum leaves }+5 \% \text { molasses }\end{array}$ \\
& $\begin{array}{l}\text { Daun sorgum }+5 \% \text { tetes }+1 \% \text { urea } \\
\text { Sorgum leaves }+5 \% \text { molasses }+1 \% \text { urea }\end{array}$ \\
& Daun sorgum $+3 \%$ tetes $+1 \%$ urea \\
3 & Sorgum leaves $+3 \%$ molasses $+1 \%$ urea \\
4 & Daun sorgum $+5 \%$ tetes + L. plantarum isolate \\
& Sorgum leaves $+5 \%$ molasses + L. plantarum isolate \\
& Daun sorgum $+5 \%$ tetes $+1 \%$ urea + L. plantarum isolate \\
& Sorgum leaves $+5 \%$ molasses $+1 \%$ urea + L. plantarum isolate \\
& Daun sorgum $+3 \%$ tetes $+1 \%$ urea + L. plantarum isolate \\
& Sorgum leaves $+3 \%$ molasses $+1 \%$ urea + L. plantarum isolate \\
& Kontrol \\
& Control
\end{tabular}




\section{HASIL DAN PEMBAHASAN}

\section{Komposisi Kimia Daun Sorgum Sebelum Ensilasi}

Komposisi kimia bahan sebelum difermentasi (ensilasi) ditampilkan pada Tabel 2. Beberapa komponen penting dari daun sorgum yang perlu diperhatikan adalah $\mathrm{pH}$, kadar protein, kandungan selulosa dan lignin, kandungan serat serta kandungan air.

Bahan silase berupa daun sorgum memiliki pH sekitar 6. Kadar protein daun sorgum sekitar $8,90 \%$ berat basah atau $4,82 \%$ berat kering. Nilai ini hampir sama bila dibandingkan nilai protein kasar pucuk tebu sebesar 4,71\% (Nyakira et al., 2015).

Kandungan selulosa dan lignin bahan digambarkan dari hasil analisis ADF. Makin besar nilai $\mathrm{ADF}$ makin tinggi kadar selulosa dan ligninnya. Nilai ADF daun sorgum sebesar 46,68\% (Tabel 2). Menurut Govea et al. (2010), hasil analisis ADF daun sorgum yang dipanen semakin tua semakin meningkat. Pemanenan pada tingkat kemasakan hard dough diperoleh nilai ADF daun sorgum 40,3\%.

Kandungan serat/fiber dari daun sorgum dapat dilihat dari nilai NDF. Nilai NDF sebesar $82,71 \%$ menggambarkan besarnya kandungan serat/fiber dari daun sorgum yang berupa hemiselulosa, selulosa dan lignin. Hemiselulosa adalah serat/fiber yang mudah dicerna oleh sistem pencernaan. Kandungan hemiselulosa daun sorgum sebesar 38,78\%. Selulosa merupakan serat yang dapat dicerna sebagian dalam sistem pencernaan. Kandungan selulosa daun sorgum sebesar $29,51 \%$. Lignin adalah komponen yang paling sulit dicerna dalam sistem pencernaan. Kandungan lignin pada daun tebu sebesar $7,49 \%$.

Kandungan air daun sorgum sebesar 45,76\%. Untuk pembuatan silase, kadar air optimum pada awal proses diupayakan sekitar $65 \%$. Oleh karena itu penambahan tetes, urea dan mikroba asam laktat dalam kultur cair dilakukan untuk meningkatkan kadar air pada awal ensilase. Kondisi ini dapat memudahkan proses fermentasi. Hijauan dengan kadar air tinggi pada proses ensilase menyebabkan silase menjadi tidak disukai ternak. Sedangkan hijauan dengan kadar air yang rendah (di bawah 50\%) akan berakibat proses fermentasi yang terbatas, sehingga konsentrasi asam laktat rendah, dan pH yang tinggi (Muck, 1988).

Tabel 2. Komposisi kimia daun sorgum sebelum ensilasi

Table 2. Chemical composition of sorghum leaves and stalks before ensiling

\begin{tabular}{|c|c|}
\hline $\begin{array}{l}\text { Parameter } \\
\text { Parameters }\end{array}$ & $\begin{array}{c}\text { Daun } \\
\text { sorgum } \\
\text { Sorghum } \\
\text { leaves } \\
\end{array}$ \\
\hline $\begin{array}{l}\mathrm{pH} \\
\mathrm{pH}\end{array}$ & 6,28 \\
\hline $\begin{array}{l}\text { Protein kasar }(\%) \\
\text { Crude protein }(\%)\end{array}$ & 8,90 \\
\hline $\begin{array}{l}\text { Serat tak larut dalam } \\
\text { deterjen asam }(\%)\end{array}$ & 46,68 \\
\hline $\begin{array}{l}\text { Acid detergent fiber }(A D F) \\
(\%)\end{array}$ & \\
\hline $\begin{array}{l}\text { Serat tak larut dalam } \\
\text { deterjen netral }(\%)\end{array}$ & 82,71 \\
\hline $\begin{array}{l}\text { Neutral detergent fiber } \\
(N D F)(\%)\end{array}$ & \\
\hline $\begin{array}{l}\text { Hemiselulosa }(\%) \\
\text { Hemicellulose }(\%)\end{array}$ & 38,78 \\
\hline $\begin{array}{l}\text { Selulosa }(\%) \\
\text { Cellulose }(\%)\end{array}$ & 29,51 \\
\hline $\begin{array}{l}\text { Lignin }(\%) \\
\text { Lignin }(\%)\end{array}$ & 7,49 \\
\hline $\begin{array}{l}\text { Kadar abu }(\%) \\
\text { Ash content }(\%)\end{array}$ & 3,61 \\
\hline $\begin{array}{l}\text { Kadar air }(\%) \\
\text { Moisture }(\%)\end{array}$ & 45,76 \\
\hline
\end{tabular}


pH Silase Daun Sorgum Hasil Ensilasi

Stabilitas silase dalam waktu lama sangat dipengaruhi oleh nilai $\mathrm{pH}$. Silase dengan nilai $\mathrm{pH}$ kurang dari 4 menunjukkan silase yang baik untuk disimpan dalam waktu lama (Ozturk et al., 2006). Silase dengan pH rendah dapat menghambat kerusakan silase akibat aktivitas Entobacteria dan Clostridia serta meningkatkan hidrolisis hemiselulosa dari silase. Penurunan $\mathrm{pH}$ juga terjadi pada proses ensilase sorgum manis.

Terjadinya penurunan $\mathrm{pH}$ silase akibat adanya asam laktat adalah indikator keberhasilan dalam proses ensilase. Silase yang diperoleh dari hasil ensilasi beberapa perlakuan daun sorgum memiliki $\mathrm{pH}$ seperti disajikan pada Gambar 1. Data pada Gambar 1 menunjukkan $\mathrm{pH}$ sesudah ensilasi lebih rendah dari pada $\mathrm{pH}$ sebelum ensilasi. Penurunan $\mathrm{pH}$ ini disebabkan oleh adanya asam-asam yang dihasilkan selama ensilasi. Semakin besar penurunan $\mathrm{pH}$ semakin banyak konsentrasi asam yang diperoleh. Namun demikian pada percobaan ini belum sampai pada tahap identifikasi jenis-jenis asam dan kuantitasnya dalam silase tersebut. Shah et al. (2017) menyebutkan bahwa jenisjenis asam yang biasa dihasilkan dalam silase adalah asam laktat, asam asetat, asam propionat, dan asam butirat.

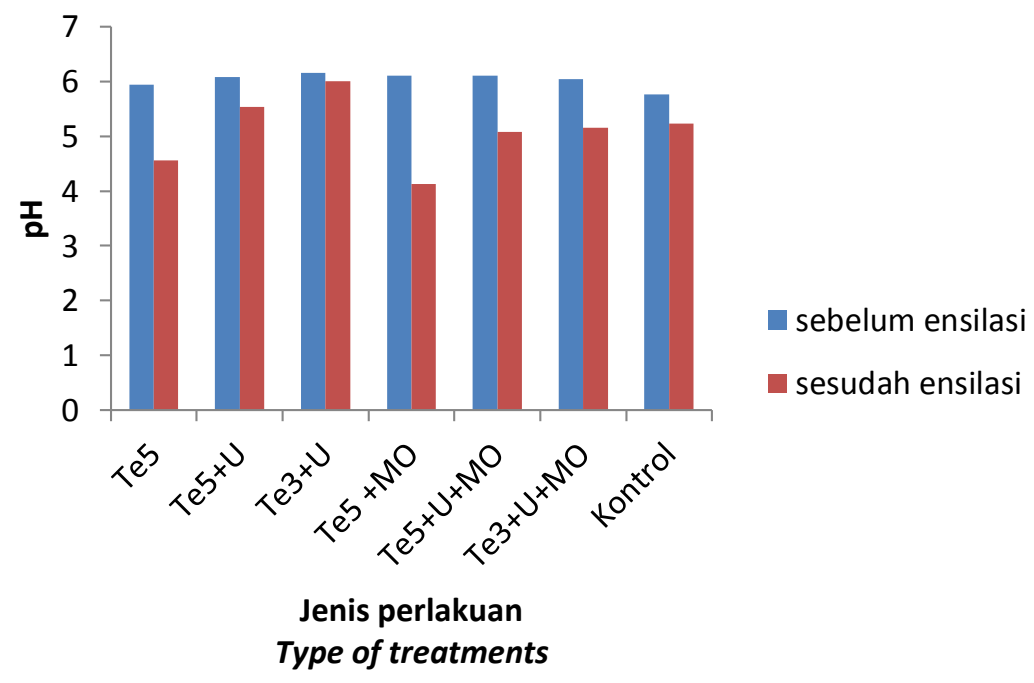

Gambar 1. Kondisi pH sebelum dan sesudah ensilasi daun sorgum pada beberapa perlakuan pemberian tetes $5 \%(\mathrm{Te} 5)$, tetes $5 \%$ dan urea $1 \%(\mathrm{Te} 5+\mathrm{U})$, tetes $3 \%$ dan urea $1 \%$ (Te3+U), tetes $5 \%$ dan L. plantarum (Te5+MO), tetes $5 \%$, urea $1 \%$ dan L. plantarum (Te5+U+MO), tetes $3 \%$, urea $1 \%$ dan L. plantarum (Te3+U+MO), dan kontrol.

Figure 1. $\mathrm{pH}$ condition before and after ensilation of sorghum leaves in several treatments by adding molasses 5\% (Te5), molasses 5\% and urea $1 \%($ Te 5+U), molasses 3\% and urea $1 \%(\mathrm{Te} 3+U)$, molassses $5 \%$ and L. plantarum $(\mathrm{Te} 5+\mathrm{MO})$, molasses $5 \%$, urea $1 \%$ and L. plantarum $(T e 5+U+M O)$, molasses $3 \%$, urea $1 \%$ and L. plantarum $(T e 3+U+M O)$, and control. 


\section{Kualitas Silase}

Kualitas silase dikelompokkan berdasarkan Nilai Fleigh (Fleigh Number/FN) (Koc et al., 2010; Idikut et al., 2009; Gurbuz and Kaplan, 2008; dan Oztrurk et al., 2006). Kualitas silase dengan FN kurang dari 20 dinyatakan kurang, 25-40 menunjukkan cukup, nilai 55-60 menunjukkan silase berkualitas sedang, 60-80 menunjukkan nilai kualitas baik sedangkan 80-100 merupakan nilai untuk silase yang berkualitas sangat baik.

Hasil percobaan berdasarkan FN dari silase daun sorgum ditampilkan pada Gambar 2. Kisaran FN silase daun sorgum antara 3592. Nilai FN maksimum untuk kualitas silase pada percobaan ini adalah 100 . Kualitas silase daun sorgum yang tergolong sangat baik dengan nilai FN 87 dan 92 berturut-turut untuk perlakuan dengan penambahan tetes dan penambahan tetes+mikroba asam laktat. Silase daun tebu berkualitas sedang (nilai FN antara 55-60) diperoleh pada daun sorgum dengan perlakuan penambahan tetes dan mikroba asam laktat. Perlakuan penambahan tetes dan urea pada daun sorgum menghasilkan silase dengan kualitas kurang baik karena nilai FNnya rendah. Nilai FN rendah ini disebabkan karena $\mathrm{pH}$ silase tinggi. Kondisi $\mathrm{pH}$ silase berbanding terbalik dengan nilai FN. Semakin rendah $\mathrm{pH}$ silase, semakin banyak asam laktat yang ada sehingga kualitas silase yang diperoleh juga semakin baik.

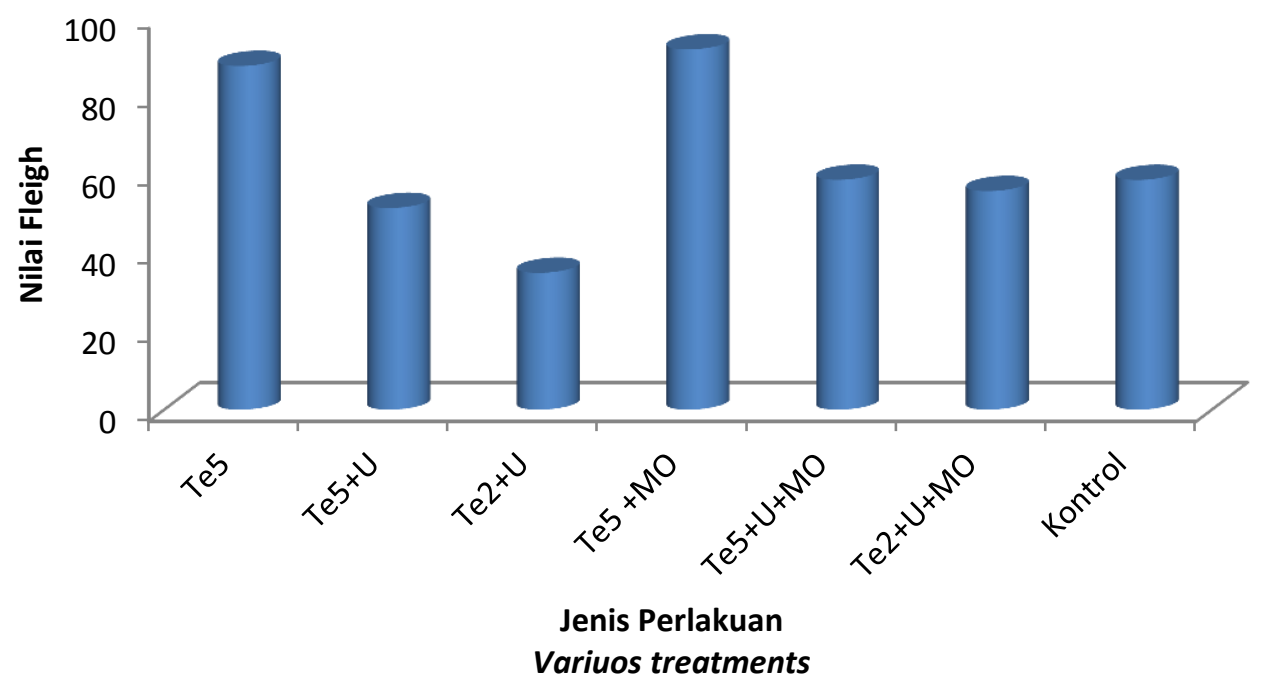

Gambar 2. Nilai Fleigh (FN) silase daun sorgum pada beberapa perlakuan pemberian tetes 5\% (Te5), tetes $5 \%$ dan urea $1 \%(\mathrm{Te} 5+\mathrm{U})$, tetes $3 \%$ dan urea $1 \%(\mathrm{Te} 3+\mathrm{U})$, tetes $5 \%$ dan L. plantarum (Te5+MO), tetes $5 \%$, urea $1 \%$ dan L. plantarum (Te5+U+MO), tetes $3 \%$, urea $1 \%$ dan L. plantarum (Te3+U+MO), dan kontrol.

Figure 2. Fleigh Number $(F N)$ of leaves sorghum silage in several treatments by adding molasses 5\% (Te5), molasses 5\% and urea $1 \%($ Te $5+U)$, molasses $3 \%$ and urea $1 \%$ $(\mathrm{Te} 3+U)$, molassses $5 \%$ and $\mathrm{L}$. plantarum $(\mathrm{Te} 5+\mathrm{MO})$, molasses $5 \%$, urea $1 \%$ and $\mathrm{L}$. plantarum $(T e 5+U+M O)$, molasses $3 \%$, urea $1 \%$ and L. plantarum $(T e 3+U+M O)$, and control. 
Nilai Nutrisi Silase Daun Sorgum

Nilai nutrisi silase daun sorgum diamati dari parameter kandungan protein, kandungan serat sulit dicerna (Acid Detergent Fiberl $A D F$ ), total pakan yang dapat dicerna (Total Digestible Nutrient/TDN) dan energi yang dapat digunakan untuk metabolisme (Metabolizable energy/ME). Tabel 3 menunjukkan nilai nutrisi silase daun sorgum. Adapun Tabel 4 menunjukkan standar kualitas pakan berdasar nilai nutrisi menurut (Quarberg, 2011).

Tabel 3. Nilai nutrisi silase daun sorgum

Table 3. Nutrition value of leaves sorghum silage

\begin{tabular}{|c|c|c|c|c|}
\hline $\begin{array}{l}\text { Perlakuan } \\
\text { Treatments }\end{array}$ & $\begin{array}{l}\text { Crude } \\
\text { Protein } \\
\%\end{array}$ & $\begin{array}{c}\mathrm{ADF} \\
\%\end{array}$ & $\begin{array}{c}\text { TDN } \\
\%\end{array}$ & $\begin{array}{c}\mathrm{ME} \\
\mathrm{Mkal} / \mathrm{lb}\end{array}$ \\
\hline Daun sorgum $+5 \%$ tetes & 8,97 & 34,03 & 58,24 & 1,10 \\
\hline Sorghum leaves $+5 \%$ molasses & & & & \\
\hline Daun sorgum $+5 \%$ tetes $+1 \%$ urea & 9,03 & 34,01 & 58,26 & 1,09 \\
\hline Sorghum leaves $+5 \%$ molasses $+1 \%$ urea & & & & \\
\hline $\begin{array}{l}\text { Daun sorgum }+3 \% \text { tetes }+1 \% \text { urea } \\
\text { Sorghum leaves }+3 \% \text { molasses }+1 \% \text { urea }\end{array}$ & 9,15 & 32,82 & 59,27 & 1,10 \\
\hline $\begin{array}{l}\text { Daun sorgum }+5 \% \text { tetes }+ \text { L. plantarum } \\
\text { Sorghum leaves }+5 \% \text { molasses }+ \text { L. plantarum }\end{array}$ & 10,9 & 37,28 & 55,49 & 1,04 \\
\hline $\begin{array}{l}\text { Daun sorgum }+5 \% \text { tetes }+1 \% \text { urea }+\mathrm{L} \text {. plantarum } \\
\text { Sorghum leaves }+5 \% \text { molasses }+1 \% \text { urea }+L . \\
\text { plantarum }\end{array}$ & 11,5 & 32,10 & 59,88 & 1,11 \\
\hline $\begin{array}{l}\text { Daun sorgum }+3 \% \text { tetes }+1 \% \text { urea }+L . \text { plantarum } \\
\text { Sorghum leaves }+3 \% \text { molasses }+1 \% \text { urea }+L \text {. } \\
\text { plantarum }\end{array}$ & 12,8 & 36,13 & 56,46 & 1,05 \\
\hline $\begin{array}{l}\text { Kontrol (Daun sorgum) } \\
\text { Control (sorghum leaves) }\end{array}$ & 8,91 & 40,47 & 52,78 & 0,99 \\
\hline
\end{tabular}

Keterangan $: \mathrm{ADF}=$ Acid detergent fiber

$\mathrm{TDN}=$ Total digestible nutrient

$\mathrm{ME}=$ Metabolizable energy

Berdasarkan Tabel 3 tampak bahwa penambahan kultur L. plantarum dapat meningkatkan kadar protein silase lebih tinggi bila dibandingkan tanpa penambahan kultur L. plantarum. Kandungan protein kasar silase daun sorgum meningkat pada perlakuan penambahan tetes saja; tetes dan urea; serta kombinasi tetes, urea dan kultur. Penambahan kombinasi tetes, urea dan kultur
L. plantarum dapat meningkatkan kadar protein hingga $3,27 \%$. Silase yang dalam proses pembuatannya tanpa penambahan kultur L. plantarum hanya meningkatkan kadar protein sebesar 0,24\%. Penambahan tetes saja hanya meningkatkan kadar protein 0,06\%. Penambahan tetes dan kultur $L$. plantarum dapat meningkatkan kadar protein $1,27 \%$. 
Tabel 4. Standar kualitas pakan berdasar nilai nutrisi

Table 4. Standard of forage quality based on nutrition value

\begin{tabular}{|c|c|c|c|c|}
\hline $\begin{array}{l}\text { Tingkatan kualitas } \\
\text { Quality grade }\end{array}$ & $\begin{array}{l}\text { Protein kasar }(\%) \\
\text { Crude protein }(\%)\end{array}$ & $\begin{array}{l}\mathrm{ADF}(\%) \\
A D F(\%)\end{array}$ & $\begin{array}{l}\text { TDN (\%) } \\
T D N(\%)\end{array}$ & $\begin{array}{l}\mathrm{ME}(\mathrm{Mcal} / \mathrm{lb}) \\
M E(\text { Mcal/lb) }\end{array}$ \\
\hline $\begin{array}{l}\text { Sangat baik } \\
\text { Very good }\end{array}$ & $>16$ & $<36$ & $\geq 56$ & $\geq 0,94$ \\
\hline $\begin{array}{l}\text { Baik } \\
\text { Good }\end{array}$ & $13-15$ & $36-37$ & $54-55$ & $0,90-0,93$ \\
\hline $\begin{array}{l}\text { Rata-rata } \\
\text { Average }\end{array}$ & $10-12$ & 38-39 & $52-53$ & $0,85-0,89$ \\
\hline $\begin{array}{l}\text { Cukup } \\
\text { Fairly }\end{array}$ & $8-9$ & $40-45$ & $49-51$ & $0,80-0,84$ \\
\hline $\begin{array}{l}\text { Kurang } \\
\text { (Poor) }\end{array}$ & $<8$ & $>45$ & $<49$ & $<0,80$ \\
\hline
\end{tabular}

Keterangan $: \mathrm{ADF}=$ Acid detergent fiber

TDN $=$ Total digestible nutrient

$\mathrm{ME}=$ Metabolizable energy

Data hasil percobaan menunjukkan bahwa nutrisi silase batang sorgum pada semua perlakuan berkisar 8,97-12,18\%. Ini artinya berdasarkan parameter kandungan protein kasar silase daun sorgum dalam percobaan termasuk dalam kategori cukup dan rata-rata. Kandungan protein silase batang sorgum meningkat pada semua perlakuan dibandingkan kontrol. Namun demikian, perlakuan penambahan tetes, urea dan pemberian mikroba asam laktat pada sampel silase batang sorgum tidak dapat meningkatkan ke dalam kelompok kualitas silase yang baik atau sangat baik. Nutrisi silase daun sorgum berkualitas baik ditunjukkan oleh perlakuan tetes $2,5 \%$, urea $1 \%$, dan mikroba asam laktat yaitu diperoleh kandungan protein kasar 12,18\% .

Nilai nutrisi silase daun dan batang sorgum ditinjau dari kadar ADF termasuk dalam kelompok kualitas baik hingga sangat baik yaitu nilai ADF kurang dari 37\% (Tabel 3). Perlakuan penambahan tetes, urea dan pemberian mikroba asam laktat dapat meningkatkan kualitas silase dari cukup menjadi kualitas baik hingga sangat baik ditinjau dari parameter ADF (Tabel 4).

Nilai nutrisi silase daun dan batang sorgum ditinjau dari parameter total kecernaan nutrisi (TDN) termasuk dalam kelompok kualitas baik hingga sangat baik dengan nilai TDN lebih dari 54\% (Tabel 3). Perlakuan penambahan tetes, urea dan pemberian mikroba asam laktat dapat meningkatkan kualitas silase dari rata-rata menjadi kualitas baik hingga sangat baik ditinjau dari parameter TDN (Tabel 4).

Nilai nutrisi silase daun dan batang sorgum ditinjau dari energi yang dapat digunakan untuk metabolisme (Metabolizable energy/ME) termasuk kelompok kualitas sangat baik dengan nilai ME lebih dari 0,94 Mkal/lb (Tabel 3). Hal juga menunjukkan bahwa perlakuan penambahan tetes, urea dan pemberian mikroba asam laktat dapat meningkatkan ME silase dibandingkan kontrol. Semakin tinggi nilai ME maka akan semakin baik kualitas silasenya. 


\section{KESIMPULAN}

Silase daun sorgum manis yang dibuat dengan fermentasi anaerob memiliki kualitas dan nilai nutrisi yang baik untuk pakan ternak ruminansia. Kualitas silase daun sorgum manis dari parameter penurunan $\mathrm{pH}$ semakin besar semakin baik kualitas silasenya. Kualitas silase daun sorgum tergolong sedang hingga sangat baik dengan Nilai Fleigh (FN) 56-92. Nutrisi silase daun sorgum berdasar kandungan protein yang tersedia termasuk kelompok kualitas cukup dan rata-rata yaitu berkisar antara $8-12 \%$. Nilai nutrisi silase daun dan batang sorgum berdasar kandungan serat yang sulit dicerna (ADF), total serat yang dapat dicerna (TDN) dan energi metalobisme pakan (ME) termasuk dalam kelompok kualitas baik hingga sangat baik dengan nilai ADF kurang dari 37\%, TDN lebih dari 54\%, dan ME lebih dari 0,94 Mkal/lb.

\section{UCAPAN TERIMA KASIH}

Terima kasih kami ucapkan kepada Tim Kerjasama Sorgum Jepang-LIPI-P3GI Tahun 2013 dalam rangka Uji Adaptasi Sorgum Varietas B6 di Pasuruan yang telah menyediakan bahan untuk penelitian ini.

\section{DAFTAR PUSTAKA}

Gallo, A., Giuberti, G., Bruschi, S., Fortunati, P. \& Masoero, F. (2016) Use of principal factor analysis to generate a corn silage fermentative quality index to rank well- or poorly preserved forages. J Sci Food Agric. 96: 16861696.

Govea, F.E.C, Marsalis, M.A., Lauriault, L.M., \& Bean, B.W. (2010) Forage sorghum nutritive value: A review. Forage and Grazinglands doi:10.1094/FG2010-0125-01-RV.
Gurbuz, Y. \& Kaplan, M. (2008) Chemical composition, organic matter digestibility, in vitro gas production characteristics and ensiling of sugar beet leaves as alternative feed resource. Journal of Animal and Veterinary Advances. 7 (12), 1568-15574.

Idikut, L., B.A. Arikan, M. Kaplan, I. Guven, A.I. Atalay \& A. Kamalak. (2009) Potential nutritive value of sweet corn as silage crop with and with out corn ear. Journal of Animal and Veterinary Advances. 8(4), 734-741.

Khan, N.A., Yu,P., Ali, M., Cone, J.W. \& Hendriksa, W.H.. (2015) Nutritive value of maize silage in relation to dairy cow performance and milk quality. $J$ Sci Food Agric. 95, 238-252.

Koc, F., C. Polat \& M.L. Ozduven. (2010) The effect of wet brewer's grain whole plant maize mixture silages on fermentation characteristics and nutrient digestibility in lambs. Poljoprivreda. 16(2), 35-41.

Manyawu, G., Chakoma, I., Gwezuva, K., Gwiriri, L., \& Moyo, S. (2016) Principles of silage making in the subtropics. International Livestock Research Institute extension brief. 1-4.

Moran, J. (2005) Tropical Dairy : Feeding management for small holder dairy farmers in the humid tropics. Landlinks Press. pp 312.

Muck, R.E. (1988) Factors influencing silages quality and their implication for management. Journal Dairy Science. 71, 2992-3002.

Nyakira B. S., Tuitoek J. K., Onjoro P. A. and Ambula M. K. (2015) Determination of the Nutritive Value of Sugar Cane Tops, Mulberry Leaves $(M$. Alba) and Calliandra (C.Calothyrsus) as Feed Supplements for Goats in Kenya. J Anim Sci Adv. 5(3), 12251233. 
Oliveira, I.L., Lima, L.M., Casagrande, D.R., Lara, M.A.S. \& Bernardes, T.F. (2017) Nutritive value of corn silage from intensive dairy farms in Brazil. Revista Brasileira de ZootecniaBrazilian Journal of Animal Science. 46(6), 494501.

Oztrurk, D., Kizilsimsek, M., Kamalak, A., Canbolat, O., \& Ozkan, C.O. (2006) Effect of ensiling alfalfa with wholecrop maize on the chemical composition and nutritive value of silage mixture. Asian-Australian Journal Animal Science. 19(4), 526532.

Pahlow, G., Muck, R.E., Driehuis, F., Elferink, S.O.\& Spoelstra, S.F. (2003) Microbiology of Ensiling. Silage
Science and Technology. Agronomi. Monograph. 42, 1-63.

Quarberg, D. (2011) Buyer's Guide To Forage Products. Cooperative extention service. University of Alaska Fairbank.

Sariubang, M. \& Nurhayu, A. (2015) Pengaruh Pemberian Silase Pucuk Tebu sebagai Substitusi Hijauan terhadap Produktivitas Sapi Potong di Kabupaten Gowa Sulawesi Selatan. Prosiding Seminar Nasional Teknologi Peternakan dan Veteriner. 146-152.

Shah, A.A., Xianjun, Y., Zhihao, D., Siran, W. \& Tao, S. (2017) Effects of lactic acid bacteria on ensiling characteristics, chemical composition and aerobic stability of king grass. The Journal of Animal \& Plant Sciences, 27(3), 747755 